\title{
The Challenges And Successes Of Department Governance: A Look At HBCU Journalism And Mass Communications Unit Administrators
}

\author{
Jerry Crawford, II, University of Kansas, USA
}

\begin{abstract}
Historically Black Colleges and Universities (HBCUs) are facing challenges to their continued existence on several fronts. One is fiscally, as federal funding for education has been cut and the responsibility for paying for higher education has been levied on students and parents. Another challenge is the amount of endowment dollars available to them and lastly, there are questions today as to if HBCUs are still needed in a society that has allowed African-Americans to enroll in Predominantly White Institutions (PWIs).
\end{abstract}

Administrators of the 55 Journalism and Mass Communication (JMC) units at HBCUs have to lead with an eye on tradition while dealing with current financial issues. The administrators are faced with the personal challenge of tenuous term limits - served at the discretion of higher administrators - and teaching two or three classes. They work under larger units and have minimal authority over budgets, hiring, or strategic planning for their units.

Their faculty work full course loads and few have tenure.

How do they keep the institution's mission and move to the future of possible accreditation?

Keywords: Historically Black Colleges and Universities; Journalism/mass Communications; Predominantly White Institutions

\section{INTRODUCTION}

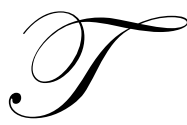

his study analyzed the results of a web survey sent to 21 unit administrators of Historically Black Colleges and Universities (HBCUs) with schools of Journalism/Mass Communications (JMC). The survey explored the attributes and thoughts these administrators have in how they guide their individual units. The study provides a basis for future research on the governance of HBCU JMC units in areas to include research, teaching, tenure, funding, and accreditation.

Educational leadership within a college or university's units makes them strong and, at times, vulnerable for failure if the leaders are not able to work within the unit's mission statement and culture, yet be innovative enough to look forward for opportunities for institutional success. HBCUs are facing challenges to their continued existence on several fronts. One is fiscally since federal funding for education has been cut and the responsibility for paying for higher education has been levied on students and parents. Another challenge is the amount of endowment dollars available to them and lastly, there are questions today as to if HBCUs are still needed in a society that has allowed African-Americans to enroll in Predominantly White Institutions (PWIs).

How are administrators at HBCU JMC units chosen? How do they operate day to day? How do they interact with faculty and students? This study is important because HBCU JMC units produce the majority of 
journalists in America, and in a democratic society, a loss of minority voices is a danger to its freedom. A loss of African-American voices could be a result if HBCU JMC units fail.

\section{WHY JOURNALISM AT HBCUS IS IMPORTANT}

The press in the early American colonies spoke out about what they considered to be tyranny from England and was determined to let everyone know the issues of the day. Benjamin Franklin and other newspaper printers helped to create a "collective consciousness of eighteenth-century America, thereby playing a central role in establishing the legacy of social importance that the press has enjoyed to the present day." (Frasca, 2006, p. 21)

Indeed, the idea of the masses having access to information and ideas terrified those at the top of society." (Rudin \& Lbbotson, 2002, p. 18) This challenge to authority is a key to journalism. Having different voices in a society to speak for everyone is a privilege and an obligation for journalists. "First Amendment rights and the democratic political environment of the United States have contributed to the uninhibited growth of the news media in public and private communication." (Noronha, 2005, p. 9) It is with this in mind that HBCUs continue to be a beacon to those who crave and depend on the African-American media voices.

HBCUs both educate and graduate the majority of minority voices in the United States. HBCU JMC administrators hold this responsibility in their hands as they lead their units.

\section{WHAT ARE HISTORICALLY BLACK COLLEGES AND UNIVERSITIES?}

"Historically Black Colleges and Universities (HBCUs) are black academic institutions established prior to 1964 whose principal mission was, and still is, the education of black Americans." (Roebuck \& Murty, 1993, p. 3) All HBCUs must be accredited or working toward accreditation in their states and can be junior colleges or have programs that work toward a bachelor's degree. "Ashmum Institute (now Lincoln University) was the first allAfrican American institution to remain in its original location, award baccalaureate degrees, and develop completely into a degree-granting college." (Harper, Patton \& Wooden, 2009) There have since been others added by federal agencies. HBCUs have been around for over 156 years and have served as a beacon in the African-American community for vocational, professional, political and scholarly education. The roots of designation started in Congress.

Justin Morrill, a congressman from Vermont, championed legislation in 1862 for each state to have land set aside to establish agriculture and vocational/mechanical arts. The rights for Blacks to receive these opportunities were minimal or nonexistent. Therefore, because of the "educational segregation of the Southern states, a subsequent Morrill Land Grant Act, enacted in 1890, established 16 Black colleges to serve the same purpose for the African American population." (Justiz, Wilson, \& Björk, 1994, p. 198) These new schools, and some that had previously been created, were all now known as "the '1890 colleges' to distinguish them from the 1862 land grant colleges." (Justiz, Wilson, \& Björk, 1994, p. 198) Southern states simply opened the new colleges and excluded Blacks. Some educators, such as Paul Barringer of the University of Virginia, were against educating these freed men. He said it was foolish to try to educate the former slaves while there are so many poor whites that needed to be trained for the same jobs. In stating his case, Barringer emphasized, "We cannot equip both, and to equip the Negro to the neglect of the poor white would be a grave political error and an economic absurdity." (Brooks, 1996, p. 241) The second Morrill Act demanded the southern states to create schools to educate the freed men. Unfortunately, as is reality now, the funding for these two groups of institutions were never equal or fair. Even with the differences in funding, "this second Morrill Act did eventually give rise to several historically Black agricultural and mechanical colleges." (Jones-Wilson, Asbury, Okazawa-Rey, Anderson, Jacobs, \& Fultz, 1996, p. 18)

\section{FUNDING: FOLLOW THE MONEY TO SUCCESS - THE HIGHER EDUCATION ACT OF 1965}

President Lyndon Johnson signed the act into law as part of his war on poverty, "the HEA was intended, along with the Economic Opportunity Act, the Civil Rights Act of 1964, and the Elementary and Secondary Education Act, to eliminate poverty and discrimination." (Brown \& Freeman, 2004, p. 71) What the act did was start a federal assistance program for students rather than for the institutions themselves. HBCUs historically 
provide education to students that are not able to pay the full cost of college. Students that traditionally attend HBCUs come from low-income families and HBCUs have missions that require the institutions to provide the ability for the students to attend. "In short, both student opportunities and HBCU enrollments depend upon financial aid packages." (Brown \& Freeman, 2004, p. 71)

HEA has eight sections or titles, each of them designed to aid in the education. For the purposes of this paper, Title III and Title IV will be discussed. "Title III was designed to aid historically black colleges, but was "drafted in terms that veiled the basic intent of supporting primarily black institutions."' (Parsons, 2000, p. 86) Title III allocates money for infrastructure, technology and is to be used to assist institutions. Title IV is geared toward helping individual students in their quest to go to college. "Title IV, with its four-part package of financial aid, is the heart of the HEA.

\section{ENDOWMENTS}

With the United States facing debt ceiling issues and a new congress seeking to cut social spending, HBCUs can be faced with losing this initiative in the near future. It is clear that HBCUs have not traditionally been given the same funding as other schools from either the state or federal level.

The need for the majority of their students to have to rely on Pell Grants and having lower economic family backgrounds makes it tough for HBCUs to increase their tuitions and fees to compensate for a lack of federal and state funding. In fact, HBCUs have raised their tuitions in the last several years, but they fear that if they raise them too much, African-American students may choose to attend PWIs or community colleges.

HBCUs, having lower outside funding, charging less than PWIs to attend, and having students from lower economic backgrounds have a large challenge of trying to get these same students to give back to their schools. For decades, alumni from these institutions were not even requested to help. "HBCUs neglected to ask their alumni for support, assuming that their alumni had little to give and doubting the return on investment of money and time spent cultivating alumni contributions." (Gasman, 2009) As some politicians look to cut education spending at all levels, the need exists for alumni and corporate giving to increase for HBCUs. "During difficult economic times, however, it is not easy to secure dollars from alumni not in the habit of giving." (Gasman, 2009)

The combined endowments of all HBCUs are less than 2 billion dollars, "while the endowment at Harvard University is approximately $\$ 35$ billion. Only four HBCUs - Hampton, Howard, Morehouse and Spelman - have endowments exceeding $\$ 100$ million.” (Cole, 2008)

These numbers have remained steady for decades and make it difficult for HBCUs to compete for not only potential students, but also faculty that are the best teachers, researchers, or combination of both.

\section{UNIVERSITY GOVERNANCE}

"At the broadest level, most theories assume that governance refers to the process of policy-making and macro-level decision-making within higher education." (Kezar \& Eckel, 2004) How institutions develop their structure of administration and faculty involvement is not a new phenomenon. "In 1213, the chancellor issued a Magna Charter of the University in Paris, confirmed by the Pope in 1231, that he was obliged to obtain the vote of professors in matters connected with appointments for the teaching of theology and canon law." (Shattock, 2006, p. 1)

HBCU JMC administrators are facing all these challenges. This study was geared toward gaining their insights into what their roles are in the governance structure. Many of these administrators are new to the position and are learning as they go through their first year or two on the job. What model of structured governance do they have? How do they make the system work for the betterment of the institution, students, faculty, and staff? 


\section{INSTITUTIONAL THEORY}

"Institutional theory is an emergent set of theoretical arguments about the influence of broader sets of societal values, cultural theories, ideologies, perceptions on organizational structures, and practices." (Heck, 2004, p. 150) Institutional theory provides an alternative to technical-rational conceptions of organizations. This perspective on organizations "flows from a general institutional theory of social organization, which explains that the behavior of actors, both individual and collective, expresses externally enforced institutions rather than internally derived goals." (Crawford, Kydd, \& Riches, 1997, p. 14) "Institutional theory stresses that organizational adaptation occurs due to institutional pressures for legitimacy rather than market pressures for efficiency." (Greenwood and Hinings, 1996) HBCU JMC administrators work within this framework of having their units focused as primarily teaching institutions while attempting to have at least some working professionals on staff.

This study uses institutional theory to examine the interaction and decisions HBCU JMC administrators have in their units. Although more often applied to organizational studies, the theory offers an alternative lens through which to view the behavior of actors in policy situations, as well as the behavior of organizations in adopting policy changes." (Heck, 2004, p. 150) "From the institutional perspective, policy action results from the enactment of institutional norms and rules as opposed to individuals' choices." (Ogawa, 1992) This is important due to the relatively short time the administrators in this study have been in their roles. "Meyer (1983) posited that new structures, or innovations, introduced by individuals at lower, technical levels of organizations are more likely to affect their substantive performance." Are the HBCU JMC administrators willing to allow faculty to be a part of shared governance? "Institutional theory is powerful in demonstrating the way in which organizations are linked to their environment; the role of agency is underestimated. It is therefore important to examine the processes by which strategic choice" (Child 1972) is exercised within organizations. The administrators' challenge is to make their units as successful as they can. They define success in different ways and institutional theory works because it does not give a template as to what makes the organization a success. "Institutional isomorphism stresses legitimacy over efficiency, thereby allowing for the persistence of inefficient, but legitimate, organizations." (Poole \& Van De Ven, 2004, p. 136)

\section{HBCUS WITH JOURNALISM/MASS COMMUNICATIONS UNITS}

The struggles with racism and funding, that made it difficult to have institutions of higher learning for freed Blacks and other African-Americans that were addressed with the Morrill Acts, continued with the establishment of journalism units. While the institutions could educate their students in fields such as teaching and agriculture, journalism was not among the disciplines to be offered and there were no real options for African-Americans to go to PWIs to become a journalist.

"The case of Lucille Bluford describes the reality of Blacks and American journalism and mass communication education in the era of 'separate but equal."' (Jeter, 2002) The Morrill Act did allow for this type of funding; states only had to provide access. Bluford applied for admission to the journalism school at the University of Missouri. "To avoid admitting her to the all-White school, in 1942, the state of Missouri created a new and separate journalism program at Lincoln University, the state's college for Blacks, and assigned one teacher to it." (Jeter, 2002) Of course, this was not equal. It was, however, separate and the decision started what would become the first HBCU with a unit in journalism. "The Missouri school was the only HBCU to offer journalism major until 1967 when Hampton Institute established its mass media arts major." (Jeter, 2002)

Howard University, founded in 1867, established journalism and radio-TV-film majors as part of a comprehensive communications school and admitted its first students in 1971. Howard University is still the only HBCU to offer a doctoral degree in communications.

Hampton and Howard are two of the larger HBCUs and their programs have a tradition and legacy of producing journalists and media professionals. Their administrators still have to battle the perception that their graduates do not match up with graduates from PWIs. HBCU JMC administrators have to make decisions as to the best way to refute this image. One way is to seek accreditation. 
Accreditation is granted by the Accrediting Council on Education in Journalism and Mass Communication (ACEJMC). As in most cases of accreditation of schools and programs, the aim is to ensure the curricula and outcomes of a member meets established standards. This is not to say that accreditation is the deciding factor for administrators; just that it is a choice. Accreditation creates other challenges - most noticeably, financial. The cost to apply, prepare, and implement accreditation standards is too much for many units, HBCUs, and PWIs to afford.

So HBCU JMC administrators face the challenge of using the best of the accreditation practices to ensure their students are competitive. Can the administrators hire the most qualified faculty, can they foster an atmosphere that is conducive in moving curricula forward, and will the administrator have the term and freedom to do these things?

\section{RESEARCH QUESTIONS}

This study's objective is examining how Historically Black Colleges and Universities with journalism/mass communications units operate in the leadership position. There is very little research available on this topic and this study will provide a baseline for HBCU JMC administrator studies and comparative studies with PWIs. These challenges to the HBCU JMC administrators lead to three research questions.

First, the study was interested in knowing the structure of the unit in relation to the institution. Were the units autonomous or were they part of other larger units on campus? Are the administrators charged with the responsibility of maintaining and also strategizing for the future for their units? What is the actual role they play in the administrative governance model at the institution?

RQ1: Do HBCU JMC administrators have enough independent authority to manage and lead their units?

Second, the study is interested in finding out how HBCU legacies are faring in their operational model after the first of these were established 150 years ago. More specifically, the study is interested in knowing if HBCUs with JMC units have changed since the first one - Lincoln, Missouri - was created in 1942.

RQ2: Have HBCUs had to change their missions to adapt their journalism/mass communications units to compete with other institutions?

Finally, and perhaps most important, the study wanted to know how major federal laws have worked to help HBCU JMC units since the Morrill Acts and later, the Civil Rights Act, specifically those that were geared toward breaking the segregation and limiting access to education of the 1960s and early 1970s throughout the United States.

RQ3: How have HBCU journalism/mass communications units fared under the guidelines of the Civil Rights Act of 1964 and the Higher Education Act of 1965?

\section{METHODOLOGY}

The earliest users of web-based surveys were market researchers, but now serious social researchers also use it. Computer-based interviewing is well established in telephone surveys and, since the mid-1990s, has been used to administer surveys using the Internet. "The early use of the Internet for collecting quantitative survey data relied on primitive e-mail-based methods, but the web, with its graphical interface and interactive abilities, has led to the rapid growth of sophisticated web-based surveys that make use of CAI features." (Becker \& Bryman, 2004, p. 216)

Web-based surveys allow researchers to reach more subjects and allow a benefit to individuals who want to be anonymous in their responses. The researcher also benefits. "These benefits include a faster response, protection against the loss of data, easy transfer of data into a database for analysis, cost savings, convenience for the respondent, the possibility of wider geographic coverage, and a potentially better response rate." (Mertler, 2002) 
Social researchers are frequently faced with the fact that they cannot collect data from everyone who is in the category being researched. "As a result, they rely on getting evidence from a portion of the whole in the expectation and hope that what is found in that portion applies equally to the rest of the population." (Denscombe, 2003, p. 11)

This study used a 25-question web-based survey to serve as a baseline for future research on HBCU JMC governance. The five questions chosen are indicative of the answers given by the respondents. There are 103 Historically Black Colleges and Universities in the United States and they are not a unified entity - some are fouryear, some are two-year, and there are also several with community college designations. A search of these institutions found that 49 of them had journalism/mass communications units at different layers - schools, departments, concentrations, and minors.

The decision to use a web-based survey fits well with grounded theory in examining the results given by the HBCU JMC administrators. "The approach originated with the work of Barney Glaser and Anselm Strauss and, in particular, their book, The Discovery of Grounded Theory, which was published in 1967." (Denscombe, 2003, p. 109) When using grounded theory, researchers follow systematic, analytical procedures in most versions of the approach. "Grounded theory is more structured in its process of data collection and analysis than other forms of qualitative research, even though their strategies are similar, such as thematic analysis of interview transcripts, observations, and written documents." (Daymon \& Holloway, 2002, p. 117)

"This inductive analytical process involves a constant interplay between data collection and data analysis. Essentially, as data are collected, they are analyzed for emergent theoretical categories." (Sprenkle \& Piercy, 2005, p. 42) This study collected data for over two years and systematically used as Strauss and Corbin posited, "looped back into the collection of data and analyzed further for their interrelationships and meanings." (Strauss \& Corbin, 1998) Glaser and Strauss developed grounded theory together, but, in later years, their views and thoughts differed on how the theory should be used. "Glaser emphasizes the emergent process of theory development, whereas, until his death, Strauss emphasized the systematic aspect of managing data analysis and synthesis." (Sprenkle \& Piercy, 2005, p. 45) This study uses the process championed by Strauss. "His formalized approach to coding data is especially helpful to beginning grounded theory researchers, because it helps reduce the ambiguity that generally goes along with grounded theory analysis." (Sprenkle \& Piercy, 2005, p. 45)

The data set this study received will allow for a new theory possibility as it serves as a baseline for future research.

The 25 questions on the questionnaire were developed by reading the results of 15 self-studies done by HBCUs in their attempts to gain ACEJMC accreditation over a period of three years. The questionnaire also took into account the reports of the site teams and committee reports done for ACEJMC of the HBCUs up for accreditation designation. From this information, common themes were seen and used to ask current HBCU JMC administrators how they handle these themes.

In February 2010, a survey was e-mailed to the administrator of each unit from addresses found on each school's web pages. Some institutions did not have a person listed, so an e-mail was sent to the school's chief academic officer and a phone call made to confirm receipt. A second attempt to send the survey was sent to all nonresponding schools in April as a reminder and to ask for a response. A third request was made in May and phone calls made to each person to ask for a response. In each request e-mail, the administrators were given the chance to respond via return e-mail or phone call.

The result of these requests was 21 responses from HBCU JMC administrators. The survey asked the administrators to provide information on their titles, academic rank, length of time in their roles, number of faculty, and type. The survey also asked about tenure, governance, fund raising, and the unit's interest in ACEJMC accreditation. Data from the administrators were entered into a data file.

Of the 55 institutions, it was found that six of them no longer had a journalism/mass communications track due to budget cuts and units being downsized to concentrations of larger institution units. This made the final total 
49 HBCUs with these units. The 21 administrators that responded represent $38 \%$ of the total administrators at HBCU JMC units.

Limited research has been done on HBCUs with journalism/mass communications units and the option for students to consider HBCUs as a way to become journalists and media professionals, and this study helps to provide information on these units.

\section{RESULTS AND DISCUSSION}

The use of dimensions becomes an issue in selective coding - one of three distinct coding processes - the others being open and axial coding. Selective coding limits it to only those variables that relate to the core variable. The core variable is the central category that explains the majority of the behavior in a phenomenon. It is used to systematically link subordinate categories with the core category. As the HBCU JMC administrator answers the questions, they are given the option to give their comments as part of some survey. "Selective coding is essential to grounded theory. The integration of a core category with the other categories and their properties takes grounded theory to a higher conceptual level." (Mello \& Flint, 2009)

\section{How Long Have You Been in Your Role as Administrator?}

For the purposes of this study the term dean refers to an administrator that leads a school of journalism/mass communications; chair refers to an administrator that leads a department; and director refers to an administrator that leads a concentration or any other unit under another larger unit within the institution.

Top administrators are key participants in the change process. "They are the sponsors of change and they must also assume responsibility for building an environment where all members of the HBCU feel free to help the institutions change. They must relate practical plans for change to broader institutional plans, problems, and issues." (Sims, 1994, p. 36) As with any leader, they need time to conceptualize plans and see them to completion.

Table 1 shows the amount of time each of the 21 HBCU JMC administrators has been in their current roles. The results show that five of the 21 administrators were in the first year in their roles and three more were entering their second year. An interesting part of this data is that eight of the 21 had been in their roles for more than five years and three of these administrators had been in their roles over 10 years. The longevity of these administrators is rare for HBCUs in JMC units. It was disclosed by two of these administrators that they would be resigning their positions by the end of the July 2011, thus ending 20 and 40 years of service at their institutions.

Table 1: How Long Have You Been at Your Current Position Including This Year?

\begin{tabular}{lcc}
\hline Answer Options & Response Percent & Response Count \\
\hline First year & $23.8 \%$ & 5 \\
Less than 2 years & $14.3 \%$ & 3 \\
3-5 years & $23.8 \%$ & 5 \\
5 or more years & $38.1 \%$ & $\frac{8}{21}$ \\
\hline
\end{tabular}

"Presidents and administrators of historically Black colleges and universities are often accused of being autocratic. The mission and plight of HBCUs situates them in distinctly different contexts that potentially affect campus decision-making and leadership practices." (Minor, 2004) Table 1 shows there are as many new administrators as there are longer-termed administrators.

In Tables 2 and Table 3, the academic rank and title of the administrator is used to give texture to the study's participants. Table 2 shows that 13 of the 20 administrators who responded hold the title of chair. The one administrator that skipped the question later noted in an e-mail that they were retiring and did not answer for that reason. The person noted that they held the title of chair and rank of professor. Table 3 deals with the administrators' academic rank and was surprising to find that of the 21 administrators, nine held the title of full 
professor, nine were associate professors, and two were assistant professors. The surprise was in the number of full professors; however, four of them were from institutions that held JMC programs in other disciplines, such as Languages and Literature or Humanities, and not as a separate entity.

Table 2: What Is Your Title?

\begin{tabular}{lcc}
\hline Answer Options & Response Percent & Response Count \\
\hline Chair & $60.0 \%$ & 13 \\
Director & $10.0 \%$ & 2 \\
Dean & $10.0 \%$ & 2 \\
Acting/Interim (Any of the positions) & $15.0 \%$ & $\underline{3}$ \\
& & 20 \\
\hline
\end{tabular}

Table 3: What Is Your Academic Rank?

\begin{tabular}{llc}
\hline Answer Options & Response Percent & Response Count \\
\hline Assistant Professor & $10.0 \%$ & 2 \\
Associate Professor & $45.0 \%$ & 9 \\
Professor & $45.0 \%$ & 9 \\
& & 20 \\
\hline
\end{tabular}

Question 11 on the questionnaire asked the HBCU JMC administrators what they would say the primary role of the faculty was in their unit between teaching and research. This question goes to the heart of the mission of HBCUs and may or may not take into account any thoughts of professional or academic accreditation. "Based on HBCUs' historical roots and current statements, the vision and mission of these institutions generally viewed as recognizing community as a unit of identity meriting institutional attention and support." (Sydnor, Hawkins \& Edwards, 2010) This means that HBCUs were traditionally more interested in providing a nurturing educational opportunity for students than research. Table 4 clearly shows this to be the case. Nineteen of the 21 administrators responded that teaching should be considered the faculty's primary role. One administrator that chose other gave the response "Primarily teaching with research expectation."

Table 4: How Would You Describe the Primary Role of All Faculty in the Unit?

\begin{tabular}{lcc}
\hline Answer Options & Response Percent & Response Count \\
\hline Teaching & $95.0 \%$ & 19 \\
Research & $5.0 \%$ & 1 \\
Other (please specify) & & $\frac{1}{21}$ \\
\hline
\end{tabular}

Question 13 on the questionnaire was, "On average, how many courses does each person teach each semester?" This question supports the research answers in the survey. Administrators, as seen in Table 5, reported that 18 of the 21 units have each faculty member teaching four courses per semester. One administrator reported five courses and one commented, "four courses, three preps". Faculty at HBCUs are facing the same challenges as those at PWIs in regard to teaching. Research and scholarship activities of faculty are related to the amount of time a "faculty member devotes to teaching, and as more time and energy is devoted to research, less emphasis is placed on teaching. Some researchers speculate there is a negative relationship between research and teaching." (Taylor \& Stanton, 2009)

Table 5: How Many Courses Per Semester Do Your Faculty Teach?

\begin{tabular}{ccccc}
\hline Valid & Frequency & Percent & Valid Percent & Cumulative Percent \\
2 & 1 & 4.8 & 4.8 & 4.8 \\
3 & 1 & 4.8 & 4.8 & 9.5 \\
4 & 18 & 85.7 & 85.7 & $\frac{95.2}{100.0}$ \\
5 & $\underline{1}$ & $\frac{4.8}{100.0}$ & $\underline{4.8}$ & \\
Total & 21 & 100.0 & \\
\hline
\end{tabular}




\section{HBCU JMC Administrator Comments}

Administrators were asked if there were any comments they would like to make in response to the survey or to their individual unit's operation. Following is a sample of their comments:

- $\quad$ HBCUs face a lot of financial challenges. These challenges are especially, well, challenging, in the jcomm area. J-Comm is a tech intensive program. It requires a constant influx of money to keep up with changing technology, yet it is not really considered a STEM area that attracts a lot of grant support.

- Decision-making is a collaborative effort, especially regarding important issues that affect faculty, staff and students in the department. I believe that if we are all involved in making the decisions, we are more likely to work harder toward their implementation.

- My unit consists of English and Communication Studies. At the moment, we only have one full-time tenured faculty member working in Communication Studies. English is strong in tenured and tenure track. Communication Studies is weak in this area as we have one Ph.D. who is on reduced appointment because he is also the director of Community Outreach and Engagement for Carnegie designation. The rest of the faculty are adjuncts/part-time.

- $\quad$ My role is servant to the faculty, students and administration. However, I have no real authority to pursue my individual goals. All agendas are decided by committee and/or department faculty as a whole.

\section{CONCLUSION AND IMPLICATIONS}

Historically Black colleges and universities continue to be the only viable option for thousands of AfricanAmericans students. Their tradition and mission has been to open their doors to provide college education for those of all races and to students that may come from K-12 education divisions that may not have prepared them at a level that some may dismiss their academic backgrounds as worthy of admittance. "Since their inception, Black colleges have been known to attract students who are low-income, first-generation, single parents or from underrepresented minority groups, and these institutions continue to fulfill this mission." (Allen, Jewell, Griffin \& Wolf, 2007)

"Despite the accomplishments of HBCUs, they are the subjects of considerable criticism within the higher education community." (Minor, 2004) It is with this in mind that those in governance roles at HBCUs owe it to the founders and pioneers of African-American education, from post slavery to today, to continue to help prepare students for productive careers and lives. "HBCUs play an important role in the perpetuation of Black culture, the improvement of Black community life, and the preparation of the next generation of Black leadership." (Allen, Jewell, Griffin \& Wolf, 2007)

Administrators of journalism/mass communication units at HBCUs are a part of the governance in this legacy of educators. This baseline study suggests that these administrators are still finding their way in the academy's administrative hierarchy. They do not seem to have the same authority as other units due to the fact that most of their units are part of other units on campus and share faculty and budgetary responsibilities. Only 2 of the 21 units were actually a school, while six of them were part of a larger unit. The administrators in this survey were indicative of HBCU JMC units in that eight of the 21 have been in their roles for less than two years and 17 of the 21 are appointed by higher administration and serve at that office's pleasure. This number is even more highlighted by the survey response of the administrators in that 18 of the 21 do not have a term limit; however, when you look at the response above that, eight of the 21 have been in their roles for less than two years and you see the instability in the position.

The administrators used for this study reported that their units are focused primarily on teaching, with 20 of the 21 giving this response, continuing to be true to the traditional HBCU mission. In fact, faculty in these 21 units overwhelmingly teach four courses per semester and, as a whole, the faculty are not tenured. Only three of the 21 administrators responded that their faculty teach three or fewer classes. The heavy course loads and lack of parttime or adjuncts, on average, two courses per semester. This obviously takes a lot of possible actual administrative time and limits their ability to plan and to strategize for the future. 
This look to the future for their units could involve preparing for the accreditation process. In academe, accreditation is an important achievement. "Accreditation may be the most fully developed institutionalization of the idea of accountability in higher education." (van Vught, 1994, p. 42) No unit on a campus wants to be the one unit that does not have accreditation. For journalism/mass communications, the Accrediting Council on Education in Journalism and Mass Communications (ACEJMC) awards accreditation. The HBCU JMC administrators in this study were mixed in their thoughts regarding this professional accreditation. It is rather impressive that four of the 21 administrators reported their units are accredited and, indeed, nine HBCUs have accreditation with ACEJMC, out of the total of 111 programs the organization recognizes with this distinction.

It is with this level of success that this research shows great hope in the continuation of HBCU leaderships and the leadership of its JMC administrators. "To transform the university, organizational leaders need to discover initiatives that are grand enough to serve as chariots that transcend faculty and disciplinary self-interests." (Ratcliff, Lubinescu, \& Gaffney, 2001, p. 103)

What needs to happen is increased funding by programs like Title III and Title IV, along with some selfhelp by alumni and private groups and community organizations to allow for hiring more faculty.

The institutions need to improve the rate of tenure for qualified professors and provide an opportunity for faculty that teach different disciplines to have a pathway to tenure. The institutions also need to provide a way to include faculty more in the decision in the process of hiring an administrator for the unit.

\section{LIMITATIONS AND FUTURE RESEARCH}

This study serves as a baseline research tool for the future study of Historically Black College and Universities governance. There are $103 \mathrm{HBCUs}$ and, within these institutions, roughly 49 units that teach some form of journalism or mass communications. This study received surveys back from 21 of these units; however, they represent the total population of units.

Future research should involve more longer-formatted interviews with all the leaders of the units. Researchers could add Critical Race Theory to examine the governance and operation of the units. A critical race theory in education challenges how history has portrayed race and the "uni-disciplinary focus of most analyses, and insists on analyzing race and racism in education by placing them in both a historical and contemporary context using interdisciplinary methods." (Solorzano, 1998)

Research should also include any new or continued federal and state funding acts or laws that directly benefit Historically Black Colleges and Universities. Along with this, a look at endowments and alumni-giving at each of the schools will show if HBCUs are growing the types of funding to make them on a closer level with PWIs of comparable size and scope.

Historically Black Colleges and Universities are important to the society. HBCU journalism/mass communication units are just as important because they produce the majority of African-American journalists and media voices. Democracy cannot afford to lose these voices. The administrators of these units will be key in keeping HBCUs competitive and productive. The success of these institutions can be attributed to the campus climate, the faculty, and the administrators. "Faculty members at HBCUs are committed to the education of the underserved student. Faculty are not only expected to achieve excellence in their academic work, but they are also counted on to be engaged in hands-on teaching and mentoring." (García, 2000, p. 9)

\section{AUTHOR INFORMATION}

Jerry Crawford is an assistant professor at the University of Kansas' William Allen White School of Journalism and Mass Communication. He has more than 25 years of professional experience in broadcast management. His research interests deal with the accreditation of colleges and universities, specifically Historically Black Colleges and Universities, with journalism and mass communication programs, and the ethical practices in broadcasting. Crawford teaches ethics, documentary and multimedia/convergence reporting and producing at Kansas. Crawford earned degrees at Virginia Commonwealth University, Virginia State University and Howard University. E-mail: jcrawford@ku.edu 


\section{REFERENCES}

1. Becker, S. \& Bryman, A. (Eds.). (2004). Understanding Research for Social Policy and Practice: Themes, Methods and Approaches. Bristol, England: Policy Press.

2. $\quad$ Berry, C. M. (2003, April). Hbcus Seek Accreditation. The Quill, 91, 30+.

3. Bowden, R. G. (2009). The Postsecondary Professoriate: Problems of Tenure, Academic Freedom, and Employment Law. Academy of Educational Leadership Journal, 13(3), 17+.

4. Brooks, R. L. (1996). A Strategy for Racial Equality A Strategy for Racial Equality. Cambridge, MA: Harvard University Press.

5. Brown, M. C. \& Freeman, K. (Eds.). (2004). Black Colleges: New Perspectives on Policy and Practice. Westport, CT: Praeger.

6. Child, J. (1972) Organizational structure, environment and performance: the role of strategic choice, Sociology 6: 1-22.

7. Cole, J. B. (2008, January 1). The Triumphs and Challenges of Historically Black Colleges and Universities. National Urban League. The State of Black America 99+.

8. Crawford, M., Kydd, L., \& Riches, C. (Eds.). (1997). Leadership and Teams in Educational Management. Philadelphia: Open University Press.

9. Crisologo, N. (n.d.).(2011). Statement on procedural standards in the renewal or nonrenewal of faculty appointments. Retrieved from http://www.aaup.org/AAUP/pubsres/policydocs/contents/nonreapp-stmt.htm

10. Dates, J. L. (1999). 17 Diversity and Multiculturalism. In Leadership in Times of Change: A Handbook for Communication and Media Administrators, Christ, W. G. (Ed.) (pp. 315-333). Mahwah, NJ: Lawrence Erlbaum Associates.

11. Daymon, C., \& Holloway, I. (2002). Qualitative Research Methods in Public Relations and Marketing Communications. London: Routledge.

12. Denscombe, M. (2003). The Good Research Guide for Small-Scale Social Research Projects (2nd ed.). Maidenhead, England: Open University Press.

13. García, M. (Ed.). (2000). Succeeding in an Academic Career: A Guide for Faculty of Color. Westport, CT: Greenwood Press.

14. Gasman, M. (2009, November/December). Historically Black Colleges and Universities in a Time of Economic Crisis. Academe, 95, 26+.

15. Greenwood, R. \& Hinings, C. R. (1996). Understanding radical organizational change: Bringing together the old and the new institutionalism. Academy of Management Review, 21, 1022-1054.

16. Heck, R. H. (2004). Studying Educational and Social Policy: Theoretical Concepts and Research Methods. Mahwah, NJ: Lawrence Erlbaum Associates.

17. Jeter, J. P., Rampal, K. R., Cambridge, V. C., \& Pratt, C. B. (1996). International Afro Mass Media: A Reference Guide. Westport, CT: Greenwood Press.

18. Jones, O. (2003). 7 Kicking Against the Pricks. In Technological Change and Organizational Action, Preece, D. \& Laurila, J. (Eds.) (pp. 121-142). New York: Routledge.

19. Jones-Wilson, F. C., Asbury, C. A., Okazawa-Rey, M., Anderson, D. K., Jacobs, S. M., \& Fultz, M. (Eds.). (1996). Encyclopedia of African-American Education. Westport, CT: Greenwood Press.

20. Justiz, M. J., Wilson, R., \& Björk, L. G. (Eds.). (1994). Minorities in Higher Education. Phoenix: Oryx Press.

21. Kezar, A., \& Eckel, P. D. (2004). Meeting Today's Governance Challenges: A Synthesis of the Literature and Examination of a Future Agenda for Scholarship. Journal of Higher Education, 75(4), 371+.

22. Parsons, M. D. (2000). 4 The Higher Education Policy Arena: The Rise and Fall of a Community. In Higher Education in Transition: The Challenges of the New Millennium, Losco, J. \& Fife, B. L. (Eds.) (pp. 83-103). Westport, CT: Bergin \& Garvey.

23. Losco, J. \& Fife, B. L. (Eds.). (2000). Higher Education in Transition: The Challenges of the New Millennium. Westport, CT: Bergin \& Garvey.

24. Mello, J., \& Flint, D. J. (2009). A Refined View of Grounded Theory and Its Application to Logistics Research. Journal of Business Logistics, 30(1), 107+.

25. Mertler, C. (2002). Demonstrating the Potential for Web-based Survey Methodology with a Case Study. American Secondary Education, 30(2), 49+. 
26. Meyer, J. W. (1983) Innovation and knowledge use in American public education, in W. R. Scott and J. W. Meyer (eds) Organizational Environments (pp. 233-60). Beverly Hills, CA: Sage.

27. Ogawa, R. T. (1992). Institutional theory and examining leadership in schools. International Journal of Educational Management, 6(3), 14-21.

28. Noronha, S. (2005). Careers in Communications (4th ed.). New York: VGM Career Books.

29. Ratcliff, J. L., Lubinescu, E. S., \& Gaffney, M. A. (Eds.). (2001). How Accreditation Influences Assessment. San Francisco: Jossey-Bass.

30. Roebuck, J. B., \& Murty, K. S. (1993). Historically Black Colleges and Universities: Their Place in American Higher Education. Westport, CT: Praeger.

31. Schonlau, M., Fricker, R. D., \& Elliott, M. N. (2002). Conducting Research Surveys Via E-Mail and the Web. Santa Monica, CA: Rand.

32. Shattock, M. (2006). Managing Good Governance in Higher Education. Berkshire, England: Open University Press.

33. Sims, S. J. (1994). Diversifying Historically Black Colleges and Universities: A New Higher Education Paradigm. Westport, CT: Greenwood Press.

34. Smith, L. (2010, March 1). Obama signs order boosting HBCU funding. Black Enterprise, Retrieved from http://www.blackenterprise.com/2010/03/01/obama-signs-order-boosting-hbcu-funding/

35. Solorzano, D. (1998) Critical race theory, racial and gender microaggressions, and the experiences of Chicana and Chicano scholars. International Journal of Qualitative Studies in Education, 11, 121-136.

36. Sprenkle, D. H. \& Piercy, F. P. (Eds.). (2005). Research Methods in Family Therapy (2nd ed.). New York: Guilford Press.

37. Strauss, A. L., \& Corbin, J. (1998). Basics of qualitative research: Techniques and procedures for developing grounded theory (2nd ed.). Thousand Oaks, CA: Sage.

38. Sydnor, K. D., Hawkins, A. S., \& Edwards, L. V. (2010). Expanding Research Opportunities: Making the Argument for the Fit between Hbcus and Community-based Participatory Research. The Journal of Negro Education, 79(1), 79+.

39. Taylor, R. L., \& Stanton, A. D. (2009). Academic Publishing and Teaching Effectiveness: an Attitudinal Study of Aacsb Accredited Business School Faculty. Academy of Educational Leadership Journal, 13(2), $93+$.

40. Van Vught, F. (1994). Intrinsic and extrinsic aspects of quality assessment in higher education. In Westerheijden, D. F., Brennan, J., and Massen, P. (eds.), Changing contexts of quality assessment. Utrecht: Lemma.

41. Willie, C. V., Garibaldi, A. M., \& Reed, W. L. (Eds.). (1991). The Education of African-Americans. New York: Auburn House. 